УДК 349

DOI https://doi.org/10.32849/2663-5313/2021.4.19

\title{
Наталія Карпінсъка,
}

канд. юрид. наук, дочент,

доцент кафедри иивільно-правових дисииплін

Волинського національного університету імені Лесі Украӥнки

\section{ПРАВОВА ХАРАКТЕРИСТИКА ЗАСТОСУВАННЯ ВЕТЕРИНАРНО-САНІТАРНИХ ЗАХОДІВ У ТВАРИННИЦТВІ}

Статтю присвячено характеристичі правового регулювання догляду за сільськогосподарськими тваринами та відносин щодо застосування ветеринарних препаратів з позииій застосування ветеринарно-санітарних заходів крізь призму вимог $е C$.

Всебічний аналіз наукової літератури дає змогу зробити висновок про те, що в сучасній правовій доктрині важливість санітарних та фітосанітарних заходів як інтегруючої категорії - категорії, яка стоїть на перехресті аграрної, екологічної, сочіальної та міжнародної політик - ще повною мірою не усвідомлена й тому суттєво недооцінена. Навіть вступ до СОТ та євроінтеграчійні зобов'язання не привели до якісних змін у напрямі розроблення доктринальних засад реформування законодавства, яке регулює санітарні та фітосанітарні вимоги в сільському господарстві.

Проведено аналіз методологічної основи правового забезпечення застосування ветеринарно-санітарних заходів у тваринниитві, в результаті якого виокремлено три основні методологічні засади оновлення підходів до ветеринарно-санітарних заходів: вплив активного розвитку в багатьох правових системах світу конщепиї добробуту тварин; формування фауністичного права в правовій системі України; ветеринарна безпека.

Аналізуючи розвиток вітчизняного законодавства про санітарні та фітосанітарні заходи, зроблено висновок про те, що законодавчі засади в чій сфері є досить об'ємними, розгалуженими, динамічними, тому для їх якісного дослідження потребують класифікації. Відповідно, відносини щодо застосування ветеринарно-санітарних заходів у тваринництві поділено на дві групи та охарактеризовано: відносини застосування ветеринарно-санітарних заходів щодо утримання сільськогосподарських тварин та відносини карантину тварин.

Обгрунтовано висновок про те, що необхідно відмовитись від автоматичного імплементування європейського законодавства щодо догляду за сільськогосподарськими тваринами та звернути увагу на наукову доктрину в $Є C$, яка подекуди критично очінює відповідне законодавство, вказуючи на три суттєві проблеми, що випливають із прогресивного законодавства ЄС про добробут тварин, а саме: уповільнення розвитку з 2003 року в чотирьох напрямах, нормативний парадокс законодавства про добробут тварин, в якому норми про комериійне використання тварин - спираючись на значення тварин як продукиіі - співіснують із правилами, що передають моральну повагу та захист тварин як розумних істот та визнання того, що більшість наукових звітів про добробут тварин, підготовлених Європейським органом з безпеки харчових продуктів, не були впроваджені в законодавство.

Ключові слова: тваринництво, фауністичне право, застосування ветеринарних препаратів, вимоги $\mathrm{EC}$

Постановка проблеми. Сьогодні тваринництво в Україні переживає важкі часи. Значне скорочення поголів'я, використання застарілих обладнання, засобів виробництва і технологій, важка конкурентна боротьба як на зовнішньому, так і на внутрішньому ринках - це далеко не всі проблеми, якими наразі обтяжений розвиток вітчизняного тваринництва. Особливістю сучасного етапу розвитку тваринництва слід визнати необхідність перебудови технологічних процесів для їх відповідності вимогам ЄС. При цьому переважна більшість таких вимог лежить у площині ветеринарно-санітарних заходів. 3 огляду на наведене вище актуальними $\epsilon$ питання правової специфіки відповідного застосування ветеринарно-санітарних заходів у тваринництві.

Вітчизняна доктрина містить нечисленні наукові розвідки, переважно зосереджені на еколого-правових аспектах застосування ветеринарно-санітарних заходів у тваринництві (зокрема, можна назвати дисертаційні дослідження П.О. Гвоздика [1], Т.В. Григор'євої [2], Н.В. Єремеєвої [3], Г.М. Левіної [4], Л.Д. Нечипорук 
[5], П.В. Тихого [6], В.В. Шеховцова [7], В.В. Шовкун [8]).

Метою статті є характеристика правового регулювання догляду за сільськогосподарськими тваринами та відносин щодо застосування ветеринарних препаратів 3 позицій застосування ветеринарно-санітарних заходів.

Виклад основного матеріалу. Перш ніж перейти до аналізу правової специфіки відповідного застосування ветеринарно-санітарних заходів у тваринництві, слід звернути увагу на методологічну основу правового забезпечення таких заходів. Мейнстрімом такого правового забезпечення можна назвати посилення вимог та неухильне підвищення стандартів ведення тваринництва. Розпочинаючи своє дослідження, ми проаналізуємо три, на наш погляд, найголовніші методологічні підвалини такої законодавчої тенденції.

Першою методологічною засадою слід вказати вплив активного розвитку в багатьох правових системах світу кониепиї добробуту тварин. Відголоски таких ідей знайшли відображення у вітчизняній правовій доктрині. Так, наприклад, здійснені спроби обгрунтування спроможності тварин мати не лише природні права, а й «умовну» (за авторським виразом) правосуб'єктність [5, с. 106-116]. Проблеми добробуту сільськогосподарських тварин спонукали наукові дослідження, розроблення та встановлення стандартів (особливо в СС та США), що мали етичні, виробничі, економічні, соціальні, культурні та торгові наслідки [9, с. 55-78].

Австралійський дослідник Стівен Уайт, розмірковуючи над питанням, якою має бути роль уряду в захисті тварин, доходить висновку про те, що це питання має два виміри. По-перше, існує питання про те, які зобов'язання люди несуть перед тваринами. Давно усталена етична практика в австралійському законодавстві - це «гуманне ставлення». Ця етика визнає, що тварини мають внутрішню цінність, виходячи 3 їхніх пізнавальних можливостей та/або чутливості, у зв'язку з чим вони мають право на певний захист. Однак лінія між добробутом тварин та добробутом людей проведена в точці, коли захист інтересів тварин неприпустимо заважає людським прагненням чи інтересам [10, с. 244-249]. Подібні етичні засади зазнали серйозної критики в іноземній літературі [11]. Однак морально-філософські побудови не завжди відповідають реальним правовідносинам. На небезпечність моралізування та захоплення філософськими конструкціями наголошує i B.M. Єрмоленко, який критикує алогічні спроби науковців юридичного профілю втиснути існування тварин у рамки виключно людського абстрактного мислення, наслідком якого є суспільні відносини та безпосередньо право як регулятор суспільних відносин. Учений вважає, що Значно більш прийнятною є концепція «благополуччя тварин», в основі якої лежить необхідність визнання потреб тварин жити в природних умовах та гідного ставлення до них з боку людей [12, с. 255-266].

Поява та втілення концепції добробуту тварин впливає на відносини землекористування, а саме: все більше проявляється відділення сучасного тваринництва від традиційного землекористування. Як зазначав B.I. Семчик, в останні роки використання біоресурсів у сільськогосподарському виробництві, зокрема у тваринництві, регулюється самостійними актами аграрного законодавства. За таких умов правове регулювання відносин у сфері тваринництва все більше відокремлюється від такого фактору виробництва, як земля, незважаючи на те, що розвиток тваринництва і біоресурсів неможливий без використання землі [13, с. 7-9]. Це слід визнати ще одним проявом інноваційного розвитку аграрного права [14, с. 47-52], методологічні основи якого динамічно змінюються та мають враховуватися в сучасних юридичних дослідженнях.

Другою методологічною засадою оновлення підходів до ветеринарно-санітарних заходів слід указати формування фауністичного права у правовій системі України. Предметом цієї складової частини екологічного права виступають фауністичні відносини, тобто відносини, що стосуються тваринного світу. Найбільш послідовний прибічник та розробник доктрини фауністичного права В.В. Шеховцов визначає тваринний світ як систематичну категорію для позначення сукупності дикої фауни у видовому та популяційному різноманітті, котра постійно чи тимчасово мешкає на теренах України, в межах їі континентального шельфу або виключеної морської (економічної зони). Спеціальним (родовим) об'єктом фауністичних відносин учений називає безпосередньо диких тварин та їхні популяції [15, с. 120-131]. Отже, тваринний світ розглядається не в комплексі, а шляхом роз'єднання диких та домашніх тварин [16, с. 149], при цьому різновидом домашніх є сільськогосподарські тварини.

Фауністичне право як феномен права тісно пов'язане з мораллю. Право виступає як соціальний регулятор, передусім між людьми, та регулює іх відносини з позиції добра, справедливості та рівності у відно- 
шенні однієї людини до іншої. Моральноправовий вплив на поведінку людей та їхній світогляд справляють і норми фауністичного права, забороняючи жорстоке поводження із тваринами. Адже межа між жорстокістю, проявленою до тварини, та жорстокістю відносно людей - надзвичайно тонка, і тому якщо не забезпечити гуманне ставлення до тваринного світу як моральної суспільної цінності, існують ризики регресивного розвитку соціуму і занепад духовно-етичної культури народу [17, с. 319]. Розвиток фауністичного права, яке безпосередньо не регулює відносини із сільськогосподарськими тваринами, побічно впливає на становлення в Україні законодавства про добробут тварин. Це відбувається, тому що цінності, які лягли в основу зародження та розвитку цих правових утворень, є спільними: вони полягають у цінності життя та гуманному відношенні до живої природи. У зв'язку з цим прискорення еволюційного розвитку фауністичного права та права добробуту тварин взаємно посилюють одне одного.

Третя методологічна підвалина втілена в понятті ветеринарної безпеки. Питання правового забезпечення ветеринарної безпеки є надзвичайно важливим, адже зоонози за свого розвитку мають небезпечні екологічні й соціальні наслідки [18, с. 7]. Загальновідомим є факт, що такі хвороби тварин, як сибірська виразка, сказ, трихінельоз і бруцельоз, є небезпечними і для людини. Навіть COVID-19 може переноситися сільськогосподарськими тваринами, зокрема норками. У Данії після виявлення нового штаму коронавірусу було вирішено знищити все поголів'я цих тварин у країні - майже 17 млн норок, що завдало непоправної шкоди датській хутряній індустрії найбільшій в ЄС [19].

Отже, паралельний розвиток кількох доктринальних напрямів - концептуальної ідеї добробуту тварин, еволюції фауністичного права, посилення ветеринарної безпеки в умовах глобалізованого світу відбувається із глибоким взаємопроникненням, посилюючи одне одного. Формується загальна тенденція до зміни парадигми правового забезпечення відносин людей і тварин. Це має свій безпосередній та найбільш помітний прояв саме у своїй інструментальній частині - трансформації законодавства щодо ветеринарно-санітарних заходів.

Оскільки відносини поводження із сільськогосподарськими тваринами можна оцінювати 3 різних методологічних позицій, у літературі зустрічаються різні підходи до визначення місця правового регулювання таких відносин у системі вітчизняного права.
За своїм характером ветеринарне право $\epsilon$ складовою частиною (інститутом) галузі аграрного права. У навчальній аграрно-правовій літературі правові питання ветеринарно-санітарного та епізоотичного благополуччя розглядаються в контексті правового регулювання тваринництва в сільському господарстві України [20, с. 139-158]. Це цілком логічно, адже тваринництво як найбільша сфера зайнятості ветеринарних працівників належить саме до аграрного виробництва, що є предметом аграрного права. Однак така належність досить умовна, адже, крім сільськогосподарських, ветеринари лікують і домашніх, і диких тварин. За цією ознакою ветеринарне право перетинається з природоресурсним правом, оскільки дикі та домашні тварини являють собою природний тваринний ресурс, який є одним із компонентів навколишнього природного середовища, національним багатством України. Водночас ветеринари разом із лікарями санітарної медицини запобігають поширенню епідемій заразних хвороб, якими хворіють не тільки тварини, а й люди. Ці відносини належать уже до галузі екологічного права [21, с. 37-38].

3 огляду на зазначене I.М. Дмитренко доходить висновку, що регулювання відносин ветеринарної безпеки галуззю екологічного права є цілком логічним і послідовним. У сфері екологічного права, на його думку, ветеринарну безпеку слід вважати частиною біобезпеки, адже відповідно до Закону України «Про систему біобезпеки при створенні, випробуванні, транспортуванні та використанні генетично модифікованих організмів» біологічна безпека - це стан середовища життєдіяльності людини, за якого відсутній негативний вплив його чинників (біологічних, хімічних, фізичних) на біологічну структуру і функцію людської особи в теперішньому і майбутніх поколіннях, а також відсутній незворотній негативний вплив на біологічні об'єкти природного середовища (біосферу) і сільськогосподарські рослини та тварини [21, с. 37-38]. Учений розуміє біобезпеку як стан захищеності біологічних об'єктів природного середовища від негативного впливу біологічних, хімічних, фізичних чинників, здатних вплинути на структуру та функцію живих організмів у теперішньому і майбутньому поколіннях. Отже, з огляду на зазначене I.M. Дмитренко переконаний, що ветеринарна безпека є складником біологічної безпеки, яка у свою чергу є складником екологічної безпеки як інституту екологічного права [23, с. 230].

I.C. Сюйва аналізує відносини щодо добробуту тварин під іншим кутом та вва- 
жає, що в Україні формується законодавство у сфері використання тварин у сільському господарстві (законодавство про здоров'я та благополуччя тварин), яке охоплює вимоги щодо: розведення та утримання сільськогосподарських тварин; ветеринарного обслуговування; транспортування сільськогосподарських тварин; первинної переробки продукції тваринництва (забій тварин) [24, с. 245-248].

Вбачається, що відповідна ідентифікація відносин щодо застосування ветеринарносанітарних заходів - це завдання неоднозначне та досить складне, особливо з огляду на ті глибокі трансформаційні процеси, що відбуваються нині в Україні та світі. Для того щоб спробувати відповісти на це та інші питання, що стосуються ветеринарно-санітарних заходів у вітчизняному тваринництві, слід здійснити аналіз правового забезпечення відповідних процесів.

Аналізуючи розвиток вітчизняного законодавства про СФЗ, доходимо висновку, що законодавчі засади в цій сфері є досить об'ємними, розгалуженими, динамічними. Для їх якісного дослідження та виявлення певних тенденцій використаємо їх класифікацію. Так, відносини щодо застосування ветеринарно-санітарних заходів у тваринництві поділяються на дві великі групи:

1) відносини застосування ветеринарносанітарних заходів щодо утримання сільськогосподарських тварин. Ця група відносин полягає в здійсненні належного догляду за сільськогосподарськими тваринами і виступає складовою частиною предмету правового регулювання благополуччя тварин. До цієї групи належать відносини щодо організації догляду, ідентифікації та реєстрації, харчування, лікування, транспортування, ринкового обігу, забою тощо. При цьому такі відносини мають пролонгований та розширювальний характер, оскільки застосування ветеринарно-санітарних заходів цієї групи не обмежується лише безпосередньо тваринами, але й поширюється на неїстівну тваринницьку продукцію з них;

2) відносини карантину тварин. Ці відносини є невід'ємною складовою частиною належного утримання сільськогосподарських тварин, однак вони все ж якісно відрізняються і тому підлягають окремому правовому регулюванню. Вивчаючи карантин тварин, Г. Слаута змальовує цілісну систему суспільних відносин, які формують матеріальну основу карантину тварин. Це відносини: а) запобігання епізоотіям (оперативна профілактика, а також безпосередньо профілактичний карантин); б) реагування на епізоотії (виявлення (діагностика) підкаран- тинних об'єктів, локалізація підкарантинних хвороб, ліквідація хвороб) [25, с. 69-75]. До групи відносин запобігання ми також уналежнюємо проведення ветеринарно-санітарних заходів, які здійснюються щодо побічних продуктів тваринного походження.

Спираючись на проведену класифікацію відносин щодо застосування ветеринарносанітарних заходів у тваринництві, проаналізуємо правове регулювання догляду за тваринами та лікування з позицій застосування ветеринарно-санітарних заходів.

Догляд. На думку І.С. Сюйви основні вимоги щодо використання тварин у сільськогосподарському виробництві: 1) мають грунтуватись на принципах моральності та гуманності, що виключають жорстоке поводження $з$ тваринами; 2) підпадають під санітарні заходи, тобто будь-які заходи, що проводяться для захисту життя або здоров'я тварин, які мають бути адаптовані до європейського законодавства.

Відповідно до Закону України «Про захист тварин від жорстокого поводження» використання тварин у сільському господарстві грунтується на таких принципах: жорстоке поводження із тваринами є несумісним з вимогами моральності та гуманності, спричиняє моральну шкоду людині; забезпечення умов життя тварин, які відповідають їхнім біологічним, видовим та індивідуальним особливостям; право власності та інші речові права на тварин у разі жорстокого поводження з ними можуть бути припинені за рішенням суду шляхом їх оплатного вилучення або конфіскації; заборона жорстоких методів умертвіння тварин, у тому числі отруєння тварин; відповідальність за жорстоке поводження з тваринами; забезпечення безпеки життя та здоров'я людей під час використання тварин у сільському господарстві [26].

Зазначені принципи мають бути дотримані на всіх стадіях сільськогосподарського виробництва, пов'язаного 3 утриманням та використанням тварин. Детально умови поводження із тваринами у сфері сільськогосподарського виробництва врегульовані Порядком використання тварин у сільському господарстві, затвердженим наказом Міністерства аграрної політики та продовольства України від 25 жовтня 2012 р. № 652, який розроблено на виконання Закону України «Про захист тварин від жорстокого поводження». Цей порядок поширюється на всіх власників тварин, які утримуються та розводяться для отримання продуктів і сировини тваринного походження.

Вимоги до догляду за сільськогосподарськими тваринами можна умовно поділити 
на дві групи: вимоги до умов утримання та вимоги до поводження із тваринами.

Вимоги, які стосуються умов утримання тварин, полягають у тому, що такі умови повинні відповідати їхнім фізіологічним, видовим та індивідуальним особливостям, а також задовольняти їхні природні потреби в кормах, воді, сні, рухах, у природній активності та інші потреби. Умови в приміщеннях для утримання тварин або на вигульних майданчиках, зокрема освітлення, температура, вологість, циркуляція повітря, вентиляція, концентрація газів і рівень шуму тощо, мають відповідати їхнім фізіологічним і видовим потребам та чинним нормативно-правовим актам із зазначених питань [27].

До другої групи вимог відносяться вимоги щодо поводження із тваринами. Ця група вимог концентрується на поведінці та діяльності людини відносно тварин. Такі вимоги переважно є негативно сформульованими, тобто представляють собою здебільшого заборони. Так, забороняється: а) спричиняти тваринам біль і страждання, крім випадків, коли життю і здоров'ю людей і тварин загрожує небезпека; б) використання обладнання інвентарю, які травмують тварин; в) нанесення побоїв, травм із метою примушення тварин до виконання будь-яких вимог; г) здійснювати надмірні навантаження тварин, що перевищують їхні фізіологічні можливості; д) використання для роботи хворих або недогодованих тварин; е) використання в роботі з тваринами спорядження та інших засобів, які можуть призвести до травмування, каліцтва або загибелі тварини [27]. До цієї ж групи вимог відноситься правило щодо застосування методів знеболення під час проведення таврування, біркування, знероження та кастрації тварин.

Слід констатувати, що вітчизняне законодавство досить скупо регулює відносини щодо належного догляду за сільськогосподарськими тваринами. Чинне законодавче забезпечення концентрується переважно на регламентації карантинних заходів, на контролі обігу, питаннях ветеринарно-санітарної експертизи тощо. Свропейське законодавство має суттєву якісну відмінність у цій частині: воно має розвинутий інститут благополуччя тварин, який сконцентрований на побудові належного догляду за сільськогосподарськими тваринами. Такий розвиток не випадковий, адже добробут тварин - це цінність Співтовариства, яка закріплена в Протоколі (№ 33) про захист та добробут тварин, доданому до Договору про заснування Європейського Співтовариства. До того ж досить показовим є прийняття ще у 1976 році Європейської конвен- ції про захист тварин, які утримуються на фермах. Ця конвенція розповсюджується на відносини щодо утримання та догляду за тваринами, зокрема в сучасних інтенсивних системах тваринництва, тобто в яких переважно використовуються технічні установки [28]. Для того щоб забезпечити належну реалізацію конвенційних положень, було утворено постійний комітет Європейської конвенції про захист тварин.

На основі цієї конвенції було прийнято Директиву Ради 98/58 / СС від 20 липня 1998 року щодо захисту тварин, які утримуються для сільськогосподарських потреб. Цей акт був розроблений для реалізації принципів, викладених у Конвенції, які включають забезпечення житлом, їжею, водою та доглядом відповідно до фізіологічних та етологічних потреб тварин. Відповідна Директива $є$ загальним актом, що розповсюджується на всіх сільськогосподарських тварин. Для деталізації було розроблено спеціальні правила утримання різних видів сільськогосподарських тварин. Зокрема, було прийнято Директиву Ради 1999/74/ЄС від 19 липня 1999 року щодо встановлення мінімальних стандартів для захисту курей-несучок [29]. Характерно, що вимоги цієї директиви поширюються лише на великі товарні підприємства (не менше 350 курей), а також не стосуються племінних господарств. Нормативні правила досить детальні та мають значне технічне навантаження. Наприклад, установлюють вимоги щодо розмірів та технічних особливостей систем годування і напування, сідал та гнізд. Установлюються мінімально необхідні розміри виробничих площ у розрахунку на одну курку. Цікавим є підхід до диференційованого регулювання утримання курей у клітках. Характерно, що нормотворець не робить жорстких вимог, а передбачає плавний перехід до кліткового утримання вищого рівня. Це зроблено за допомогою цікавого технікоюридичного прийому. Так, окремо встановлено правила до утримання курей у клітках старого зразка, при цьому зазначено, що держави-члени забезпечують заборону вирощування в таких клітках 31 січня 2012 року. Крім того, з 1 січня 2003 року жодні клітини старого зразка не можуть бути побудовані або введені в експлуатацію вперше. Тобто створено нормативні умови до плавного відходу від використання кліток старого зразка. При цьому встановлюються вимоги до нових кліток, які використовуватимуться після 1 січня 2002 року, відповідають більш високим вимогам та краще задовольняють потреби тварин. Ця директива включена до переліку тих, що мають імплементуватися до вітчиз- 
няного аграрного законодавства. При цьому юридичний прийом, який ми проаналізували вище, було би доречно використати і під час відображення відповідних правил у законодавстві України з метою забезпечення м'якої адаптації вітчизняних виробників.

Законодавство СС передбачає не лише вимоги до утримання, але й кореспондуючі правила щодо контролю за їх виконанням. Зокрема, серед зобов'язань України слід згадати необхідність імплементувати Рішення Комісії 2006/778/ЄС від 14 листопада 2006 року щодо мінімальних вимог до збору інформації під час перевірок місць, де розводяться певні види тварин. 32019 року цей документ утратив чинність у зв'язку з реформуванням системи контролю у сфері сільського господарства та передусім дотриманням вимог щодо СФЗ

Суть контролю, який стосується відносин щодо утримання сільськогосподарських тварин, полягає в регулярному звітуванні господарств за встановленою формою. Інформація та дані, які мають передаватися компетентним органам, передбачаються в Регламенті (СС) 2017/625, а стандартна зразкова форма встановлена Регламентом (EC) 2019/723. Характерно, що звітування відбувається з використанням електронної версії стандартної зразкової форми, що надається за допомогою комп'ютеризованої системи управління інформацією для офіційного контролю (IMSOC) [30].

$\mathrm{У}$ такий спосіб європейський нормотворець диференціює та максимально деталізує нормативне регулювання. Наприклад, окремі вимоги передбачені для утримання курей, що вирощуються на м'ясо. Такі правила встановлені Директивою Ради 2007/43/СС від 28 лютого 2007 року, якою встановлюються мінімальні правила для захисту курей, що утримуються для виробництва м'яса, і ця директива теж підлягає імплементації у вітчизняне законодавство.

Досить детально врегульовано відносини щодо утримання телят - цьому присвячена Директива Ради 2008/119/СС від 18 грудня 2008 року, якою встановлюються мінімальні стандарти для захисту телят. Аналіз їі змісту вказує на активне застосування наукового підходу під час розроблення законодавчого забезпечення. Зокрема, директива містить таке положення: «Науково визнано, що телята повинні отримувати все необхідне, що відповідає їхнім потребам як стадного виду. 3 цієї причини їх слід вирощувати в групах. Телята, як у групових приміщеннях, так і в індивідуальних загонах, повинні мати достатньо місця для фізичних вправ, контакту з іншою худобою та нормальних рухів, коли вони стоять або лежать» [31]. Вимоги директиви враховують потреби телят у комунікації (забороняється їх ізольоване утримання за винятком карантинної потреби), у достатньому вільному просторі, годуванні, житлових умовах тощо.

Спеціальне регулювання догляду встановлено і для свиней - на це спрямована Директива Ради 2008/120/ЄС від 18 грудня 2008 року, якою встановлюються мінімальні стандарти для захисту свиней [32]. Цим документом передбачаються детальні вимоги щодо належного утримання свиней, враховуючи їхні фізіологічні потреби залежно від віку, статі та стану. Також директивою багато уваги приділено диференційованому розрахунку достатньої площі для свиней, створенню належних житлових умов.

Важливо не лише автоматично імплементовувати європейське законодавство щодо догляду за сільськогосподарськими тваринами - важливо звернути увагу на думки європейських учених із цього приводу. Так, незважаючи на значні здобутки в напрямі забезпечення добробуту сільськогосподарських тварин, наукова доктрина в СС подекуди критично оцінює відповідне законодавство. У сучасній літературі наукова критика висвітлює три суттєві проблеми, що випливають із прогресивного законодавства $\mathrm{CC}$ про добробут тварин, а саме: а) уповільнення розвитку з 2003 року в чотирьох напрямах: неспроможність ініціювати сміливі нові нормативні ідеї; проблеми із застосуванням чинного законодавства; поблажливий підхід Суду СС при постановленні рішень щодо регулювання у сфері захисту тварин; перехід законодавчих органів $\mathrm{CC}$ у бік репресій проти екстремістів тварин [33]; 2) нормативний парадокс законодавства про добробут тварин, в якому норми про комерційне використання тварин - спираючись на значення тварин як продукції - співіснують із правилами, що передають моральну повагу та захист тварин як розумних істот [34]; 3) визнання того, що більшість наукових звітів про добробут тварин, підготовлених Європейським органом 3 безпеки харчових продуктів (EFSA), не були впроваджені в законодавство [35, с. 47-84].

Лікування. Неможливо применшити важливість належного регулювання відносин щодо застосування ветеринарних препаратів. Характерно, що ці відносини врегульовано не на рівні окремого закону (на кшталт Закону України «Про пестициди і агрохімікати»), а регламентовано в рамках загального Закону України «Про ветеринарну медицину». На підставі цих законодавчих положень розвинулось досить об'ємне під- 
законне регулювання. Цю сферу правовідносин теж активно зачіпає євроінтеграційна перебудова законодавства.

У СС виробництву та обігу ветеринарних препаратів приділяється значна увага. 3 набранням чинності 1 січня 1995 року Регламенту Ради (СЕС) № 2309/93 в СС уперше було встановлено централізовану процедуру дозволу на ветеринарні лікарські засоби, що дозволило продавати ветеринарні препарати на основі єдиного дозволу, що видавався на рівні союзу. До 1995 року ветеринарні лікарські засоби могли бути дозволені лише на національному рівні згідно 3 визнаними процедурами національних дозволів. Метою створення централізованої системи СС було сприяння та зміцнення безперебійного функціонування внутрішнього ринку у фармацевтичному секторі та поліпшення стану здоров'я населення і тварин шляхом створення загальноєвропейської системи дозволів на основі якості, безпеки та ефективності. До моменту впровадження централізованої процедури дозволу $\mathrm{CC}$ у 1995 році оцінка екологічних ризиків ветеринарних лікарських засобів була у сфері відповідальності держав-членів [36].

Довгий час ці відносини регулювалися Директивою Свропейського Парламенту та Ради Європи № 2001/82/СС від 6 листопада 2001 року щодо Кодексу Співтовариства для ветеринарних лікарських препаратів [37]. Цей акт також передбачений для імплементації в українське законодавство згідно з Угодою про асоціацію.

Виконуючи зобов'язання щодо наближення законодавства у сфері СФЗ, Мінагрополітики затвердило Правила належної виробничої практики ветеринарних препаратів [38], відповідно до яких належна виробнича практика являє собою організаційно-технічні вимоги, правила, які $€$ частиною системи забезпечення якості, котра гарантує, що ветеринарні препарати постійно виробляються і контролюються відповідно до стандартів якості, які відповідають їх призначенню, вимог реєстраційного досьє, відомостей досліджуваного ветеринарного препарату для клінічних випробувань або їх специфікації (п. 2). Варто зауважити, що зазначені Правила належної виробничої практики ветеринарних препаратів прийняті згідно з Директивою Комісії від 23 липня 1991 року щодо принципів і робочих вказівок належної виробничої практики для ветеринарних препаратів (91/412/ЕЕС), що встановлюе принципи та правила належної виробничої практики (GMP) лікарських засобів для застосування у ветеринарії [39]; а також
Директиви СС 2001/82/СС від 6 листопада 2001 року про Кодекс співтовариства щодо лікарських засобів для ветеринарного застосування [37].

При цьому аналіз директив ЄС щодо обігу ветеринарних препаратів свідчить, що сьогодні правове регулювання обігу ветеринарних препаратів у СС базується на таких принципах: 1) ветеринарні препарати, дозволені для продажу на європейському ринку, виготовляються лише виробниками, що мають відповідну ліцензію на виробництво (manufacturing authorization), діяльність яких регулярно інспектується компетентними уповноваженими органами; 2) кожен ветеринарний препарат, який виробляється, повинен мати реєстраційне посвідчення (marketing authorization), що засвідчує проведення його експертизи в компетентному державному органі; 3) якість лікарських засобів для ветеринарії забезпечується дотриманням виробником вимог належної виробничої практики - Good Manufacturing Practice (GMP); 4) високий рівень якості вироблених ветеринарних препаратів підтримується завдяки дотриманню постачальниками вимог належної практичної дистриб'юції [40, с. 65-76].

Як зазначають дослідники, протягом останніх років у самому ЄС тривала підготовка до реформи законодавства про ветеринарні препарати. Справа в тому, що стандарти їх виробництва там були аналогічними зі стандартами виробництва лікарських препаратів для людей. Однак з урахуванням низки аргументів стосовно суттєвих відмінностей між цими групами препаратів, зокрема щодо способів уживання людських та ветеринарних препаратів, а також у зв'язку зі спадом у розвитку ветеринарної фармації протягом останніх років, у СС виникли активні дискусії про необхідність послаблення стандартів виробництва ветеринарних препаратів. Врешті, після чотирьох років переговорів, 11 грудня 2018 року Європейський Парламент та Рада схвалили Регламент № 2019/6 щодо ветеринарних лікарських засобів та скасування Директиви 2001/82 ЄC [41]. Передбачається, що після закінчення трирічного перехідного періоду цей документ має вступити в силу з 28 січня 2022 року. Регламент охоплює всі напрями здійснення реєстрації ветеринарних препаратів у Союзі як на централізованому союзному, так і на національному рівні [42, с. 417-425].

Хоча в загальних рисах українська система реєстрації ветеринарних препаратів наближена до європейської, однак рівень правового регулювання такої реєстрації в $\mathrm{CC} \mathrm{є} \mathrm{значно} \mathrm{вищим.} \mathrm{Подальша} \mathrm{гармоніза-}$ 
ція потребує ухвалення необхідних національних правових актів, що регулюють обіг ветеринарних препаратів та вдосконалення існуючих інституційних механізмів. Ураховуючи обмеженість ресурсів фармвиробників у ветеринарному секторі порівняно з гуманною фармацією, саме лише підвищення регуляторних вимог до рівня законодавства $Є \mathrm{C}$, без урахування наявних у ньому спрощень і переваг, а також без комплексного вирішення проблем обігу ветеринарних препаратів в Україні (вилучення з ринку незареєстрованих препаратів, заборони використання у тваринництві фармацевтичних субстанцій тощо) призведе до знищення вітчизняної ветеринарної фармацевтичної індустрії [42, с. 417-425].

Вітчизняні дослідники наголошують на тому, що, оскільки ветеринарні препарати можуть бути досить небезпечними у випадку їх неналежного використання, зберігання, виробництва, транспортування тощо, господарську діяльність із виробництва ветеринарних препаратів слід вважати екологічно ризикованою, а отже, такою, що потребує дотримання вимог екологічної безпеки в процесі іï провадження [43, с. 106-113]. Європейська наукова доктрина, вивчаючи процеси, які відбуваються в галузі виробництва та виростання ветеринарних препаратів, теж підкреслює їх екологічну спрямованість. Цікаво відзначити, що публікації 90 -х років ХХ ст. роблять акцент на регулюванні залишків ветеринарних препаратів у м'ясі, на оцінці хімічних забруднень у продуктах харчування тваринного походження, призначених для споживання людиною [44, с. 183-198]. Потім фармакологічний вПлив почав оцінюватися також і з інших позицій, не лише антропоцентричних. Тенденції останніх ініціатив полягають у подоланні забруднення навколишнього середовища від залишків фармацевтичних препаратів на основі міцного та глобального співробітництва. Протягом останніх двох десятиліть науковці, регуляторні органи та Європейська Комісія визнали фармацевтичну продукцію новою екологічною проблемою. Паралельно була розроблена нормативна база для оцінки екологічного ризику фармацевтичної продукції. Результати показують, що приблизно $10 \%$ фармацевтичних продуктів відзначають потенційний ризик для навколишнього середовища. Серед ветеринарних продуктів найчастіше обговорювались як екологічно впливові гормони, антибіотики та антипаразитарні препарати [45].

Подібне відбувалося, наприклад, з ініціативами щодо протидії масовому використанню антибіотиків у тваринництві. Виник- нення та поширення патогенних мікроорганізмів, стійких до протимікробних препаратів, призвели до зростання занепокоєння 3 приводу широкого i надмірного використання антимікробних препаратів у ветеринарній медицині. Було запроваджено низку національних проектів, наприклад, з 90-х років Данія реалізувала декілька ініціатив щодо зменшення використання протимікробних препаратів. Найефективнішими правовим механізмом було визнано реалізовану з 2010 року схему «Жовтої картки», що суттєво знизило використання антибіотиків у тваринництві. Суть цього механізму полягала в тому, що фермеру, який використовував антибіотики більше норми, видавалася Жовта картка - припис на зменшення такого застосування протягом 9-ти місяців. У випадку невиконання цього завдання визначалася стратегія зменшення використання антибіотиків за допомогою ветеринара, до якої могли включатися протоколи вакцинації, зміни в управлінні тощо, а також щоквартальні візити органу влади. Фермер покриває всі ці витрати [46]. Відповідно до датського законодавства використання антимікробних засобів у тварин дозволяється лише для лікування інфекційних захворювань, а не для цілей профілактики чи стимулювання росту.

Ще одна значна проблема, породжена використанням ветеринарних препаратів, полягає в забрудненні грунту та води фармацевтичними залишками. Ці процеси разом з іншими стали основою концептуальної ідеї «One Health», відповідно до якої здоров'я людей тісно пов'язане зі здоров'ям тварин та навколишнім середовищем. У зв'язку 3 цим активізуються еколого-правові процеси. Наприклад, це вже можна спостерігати в державах-членах, таких як Нідерланди, які вживають національних заходів для поліпшення якості води шляхом захисту питної води від тонн залишків фармацевтичної продукції, що скидаються у стічні води щороку [47]. Потенційний вплив залишків фармацевтичних препаратів на людей та дику природу викликає занепокоєння, оскільки дедалі частіше повідомляються невтішні результати наукових досліджень щодо концентрацій фармацевтичних препаратів у поверхневих водах, а також їх впливу на популяції дикої природи.

У новому ветеринарному регламенті $\mathrm{CC}$ передбачається фактично змінити парадигму оцінки екологічного ризику, що несуть ветеринарні препарати. Зокрема, очікується відмова від традиційного підходу до оцінки екологічних ризиків, що базується на продуктах, та використання підходу, що грунтується на 
речовинах. Оцінка ризику на основі речовин буде зосереджена на розробленні всебічних досліджень активної речовини, на які можуть посилатися заявники нових препаратів під час підготовки заявки на отримання дозволу на використання. Хоча початкова реалізація цього підходу може вимагати досить значних ресурсів, ураховуючи обмежені дані про небезпеку та фізико-хімічні дані деяких активних речовин, у довгостроковій перспективі це заощадить ресурси для промисловості (оскільки не буде потреби повторювати дослідження, які вже існують), а також регулюючих органів, і призведе до узгоджених та надійних оцінок ризиків, що забезпечують більш всеосяжну характеристику ризиків. Відповідно до нового регламенту Комісія має три роки з моменту набуття чинності регламентом (січень 2022 р.) щоб вивчити доцільність створення такої системи досліджень. Новий регламент також уперше включає правове положення, що дозволяє відмовити в дозволі продукту, який містить речовини, що не відповідають визначеним критеріям стійкості, біоакумуляції та токсичності, коли ветеринарний лікарський засіб призначений для використання у тварин, що виробляють їжу [36].

\section{Висновки}

Традиційне ветеринарне законодавство України наразі перебуває на етапі еволюційного перетворення в законодавство щодо добробуту тварин. Основна сутність трансформації полягає у зміні методологічного підходу: якщо ветеринарне законодавство регулювало відповідні аграрні відносини 3 позицій антропоиентризму (передусім із метою захисту інтересів людини), то правовий інститут добробуту тварин - 3 позицій анімоцентризму (першочергово зосереджує увагу на гуманному відношенні до тварин, на дотриманні етичних принципів). Концептуально ідея правового забезпечення добробуту тварин має три основні рівні: а) економічний рівень (отримання економічних зисків від покращення утримання сільськогосподарських тварин); б) екологічний рівень (зменшення негативних екологічних наслідків інтенсивного тваринництва); в) етичний рівень (морально-етичний аспект поводження із сільськогосподарськими тваринами спирається на уявлення про тварину як істоту розумну, здатну відчувати біль та страждання, виражати емоції, комунікувати 3 людиною). Становленню в Україні правового забезпечення добробуту тварин сприяє специфічний фактор - імплемента иійні зобов'язання. Проте якісна трансформація методологічних підходів неможлива виключно в законодавчому вимірі - вони мають відбуватися перш за все в суспільній свідомості, що підтверджує європейський та світовий досвід.

\section{Список використаних джерел:}

1. Гвоздик П.О. Правові засади збереження біологічного різноманіття : автореф. дис ... канд. юрид. Наук : 12.00 .06 . Київ, 1999.18 c.

2. Григор'єва Т.В. Правове регулювання використання й охорони водних живих ресурсів : автореф. дис ... канд. юрид. наук : 12.00.06. Харків, 2005. $19 \mathrm{c}$

3. Єремеєва Н.В. Відшкодування шкоди, заподіяної порушенням законодавства про охорону тваринного світу : автореф. дис ... канд. юрид. наук : 12.00 .06 . Харків, 1994.19 c.

4. Левіна Г.М. Правова охорона та використання рідкісних і таких, що перебувають під загрозою зникнення, видів диких тварин : автореф. дис. ... канд. юрид. наук : 12.00.06. Київ, 2019. 21 с

5. Нечипорук Л.Д. Еколого-правове регулювання раціонального використання об'єктів тваринного світу : дис. ... канд. юрид. наук : 12.00.06. Київ, 2009. 198 с. С. 106-116.

6. Тихий П.В. Еколого-правове регулювання спеціального використання дикої фауни : автореф. дис ... канд. юрид. наук : 12.00 .06 . Харків, 2000. 20 с.

7. Шеховцов В.В. Право приватної власності на об'єкти тваринного світу: автореф. дис. ... канд. юрид. наук : 12.00.06. Харків, 2009. 20 с.

8. Шовкун В.В. Правове регулювання племінної справи у тваринництві : автореф. дис. ... канд. юрид. наук : 12.00 .06 . Київ, 2012. 19 с.

9. Lagerkvist C.J., Hess S. A meta-analysis of consumer willingness to pay for farm animal welfare. European Review of Agricultural Economics. 2011. Vol. 38. Issue 1. P. 55-78.

10. White S. Farm animal protection policymaking and the law: The impetus for change. Alternative Law Journal. 2018. 43. Issue 4. P. 244-249.

11. Garner R. Animal Ethics. Polity Press, 2005. 185 p. ; Bruce A. Animal Law in Australia: An Integrated Approach. LexisNexis, 2nd ed, 2017. Chs $1 \& 2.324$ p.

12. Yermolenko V.M. The concept of animal rights through the lens of critical analysis. Вісник Національної академї правових наук України. 2020. Вип. 4. С. 255-266

13. Семчик B.I. Аграрне право як комплексна галузь права України. Аграрне право як галузь права, юридична наука і навчальна дисиипліна : матеріали Всеукр. круг. столу (Київ, 25 травня 2012 року). Київ, 2012. С. 7-9.

14. Носік В.В. До питання про інноваційне оновлення аграрного права України: проблеми теорії і практики. Актуальні правові проблеми інноваційного розвитку агросфери : матеріали наук.-практ. конф. (Харків, 20 лист. 2020 року). Харків, 2020. С. 47-52.

15. Шеховцов В.В. Теоретико-правове розуміння тваринного світу: сутність та співвідношення із суміжними поняттями. Проблеми законності. 2020. Вип. 148. С. 120-131. 
16. Луц Д.М. Тваринний світ як об'єкт правової регламентації. Актуальні правові проблеми публічно-приватного партнерства у сфері аграрних, земельних екологічних та космічних відносин:матеріали Міжнарод. наук.-практ. конф. (Київ, 22 лист. 2013 року). Київ, 2013. С. 147-150. С. 149.

17. Шеховцов В.В. Принципи фауністичного права: правовий та морально-етичний аспекти. Актуальні правові проблеми земельних, аграрних та екологічних відносин в умовах сучасної земельної реформи : матеріали наук.-практ. конф. (Харків, 22 травня 2020 року). С. 317-319.

18. Загальна епізоотологія / Б.М. Ярчук та ін. ; за ред. Б.М. Ярчука, Л.Є. Корнієнка. Біла Церква, 2002. 656 с. С. 7.

19. В Дании закопали миллионы зараженных норок. Теперь их хотят откопать. URL: https:// www.bbc.com/russian/news-55107595

20. Коваленко Т.О., Марченко С.І. Правове регулювання господарської діяльності в агропромисловому комплексі України : навч. посіб. Київ : Юрінком Інтер, 2015. 296 с. С. 139-158.

21. Ветеринарне право : підруч. / за ред. B.М. Єрмоленка. Київ : НУБіП України, 2015 300 c. C. $37-38$.

22. Про державну систему біобезпеки при створенні, випробуванні, транспортуванні та використанні генетично-модифікованих організмів : Закон України від 31 травня 2007 р. № 1103. Відомості Верховної Ради України. 2007. № 35. Ст. 484.

23. Дмитренко I.M. Щодо питання співвідношення понять біобезпека та ветеринарна безпека в системі права України. Часопис Київського університету права. 2017. Вип. 3. С. 230-233.

24. Сюйва I.C. Правове регулювання використання тварин у сільському господарстві. Часопис Київського університету права. 2018. Вип. 4. C. $245-248$

25. Слаута Г. Предмет правового регулювання карантину тварин. Право. Людина. Довкілля. 2020. Вип. 11. № 1. С. 69-75.

26. Про захист тварин від жорстокого поводження : Закон України від 21.02.2006 р. Відомості Верховної Ради України. 2006. № 27. Ст. 230.

27. Про затвердження Порядку використання тварин у сільському господарстві наказом Міністерства аграрної політики та продовольства України від 25 жовтня 2012 р. № 652. Офіиійний вісник Украӥни. 2012. № 91. Стор. 88. Ст. 3703.

28. European Convention for the Protection of Animals Kept for Farming Purposes (Strasbourg, 10.03.1976). URL: https://ec.europa.eu/food/sites/ food/files/animals/docs/aw_european_convention_ protection animals en.pdf

29. Council Directive 1999/74/EC of 19 July 1999 laying down minimum standards for the protection of laying hens. URL: https://eur-lex. europa.eu/legal-content/EN/TXT/?uri=CELEX\%3 A31999L0074\&qid $=1610609489360$

30. Commission Implementing Regulation (EU) 2019/723 of 2 May 2019 laying down rules for the application of Regulation (EU) 2017/625 of the European Parliament and of the Council as regards the standard model form to be used in the annual reports submitted by Member States. URL: https://eur-lex.europa.eu/legal-content/en/ TXT/?uri=CELEX\%3A32019R0723

31. Council Directive 2008/119/EC of 18 December 2008 laying down minimum standards for the protection of calves. URL: https://eur-lex. europa.eu/legal-content/EN/TXT/?uri=CELEX\%3 A32008L0119\&qid $=1610615318775$

32. Council Directive 2008/120/EC of 18 December 2008 laying down minimum standards for the protection of pigs. URL: https://eur-lex. europa.eu/legal-content/EN/TXT/?uri=CELEX\%3 A32008L0120\&qid $=161061642084$

33. Pedersen N.K. 'Detailed Discussion of European Animal Welfare Laws 2003 to Present: Explaining the Downturn' (Animal Legal and Historical Center 2009). URL: https://www.animallaw.info/ article/detailed-discussion-european-animal-welfarelaws-2003-present-explaining-downturn

34. Sowery K. Sentient Beings and Tradable Product: The Curious Constitutional Status of Animals under Union Law. Common Market Laz Revieซ. 2018. Vol. 55. № 1.

35. Leone L. Farm animal welfare under scrutiny: issues unsolved by the EU legislator. European Journal of Legal Studies. 2020. Vol. 12. Issue 1. P. 47-84.

36. Fabrega J., Carapeto R. Regulatory review of the environmental risk assessment of veterinary medicinal products in the European Union, with particular focus on the centralised authorisation procedure. Environmental sciences Europe. 2020. Vol. 32. Issue 1. URL: https://enveurope.springeropen.com/ track/pdf/10.1186/s12302-020-00374-x.pdf

37. Directive 2001/82/EC of the European Parliament and of the Council of 6 November 2001 on the Community code relating to veterinary medicinal products. URL: https://eur-lex.europa.eu/ legal-content/EN/TXT/?uri=CELEX\%3A32001L0 $082 \&$ qid $=1610980303227$

38. Про затвердження Правил належної виробничої практики ветеринарних препаратів : наказ Міністерства аграрної політики та продовольства України № 606 від 10 листопада 2017 року. Офімійний вісник Украӥни. 2018. № 12. Стор. 46. Ст. 420.

39. Commission Directive $91 / 412 /$ EEC of 23 July 1991 laying down the principles and guidelines of good manufacturing practice for veterinary medicinal products. URL: https://eur-lex.europa.eu/legalcontent/EN/TXT/?uri=CELEX\%3A31991L0412\& qid $=1610980247105$

40. Березовська I.А. Правові засади Належної виробничої практики (GMP) для ветеринарних препаратів у Євросоюзі: досвід для України. Актуальні проблеми міжнародних відносин. 2018. Вип. 137. С. $65-76$

41. Regulation (EU) 2019/6 of the European Parliament and of the Council of 11 December 2018 on veterinary medicinal products and repealing Directive 2001/82/EC. URL: https://eur-lex. europa.eu/legal-content/EN/TXT/?uri=CELEX\%3 A32019R0006\&qid $=1610980458627$ 
42. Березовська I.A. Проблеми правового регулювання спрощеної реєстрації ветеринарних препаратів в Україні. Науково-технічний бюлетень Державного науково-дослідного контрольного інституту ветеринарних препаратів та кормових добавок і Інституту біологї тварин. 2019. Вип. 20. № 2. C. $417-425$.

43. Оверковська Т. Правове регулювання виробництва ветеринарних препаратів. Economic And Law Paradigm Of Modern Society. 2020. № 1. C. 106-113.

44. Anadon A., Martinez-Larranaga M. Residues of antimicrobial drugs and feed additives in animal products: regulatory aspects. Livestock Production Science. Vol. 59. Issue 2-3. P. 183-198.
45. Kuester A., Adler N. Pharmaceuticals in the environment: scientific evidence of risks and its regulation. Philosophical Transactions of The Royal Society B-Biological Sciences. 2014. Vol. 369. Issue 1656. URL: https://royalsocietypublishing. org/doi/pdf/10.1098/rstb.2013.0587

46. Antunes A.C. Lopes, Jensen V.F. Close to a Decade of Decrease in Antimicrobial Usage in Danish Pig Production-Evaluating the Effect of the Yellow Card Scheme. Frontiers In Veterinary Science. 2020. Vol. 7.

47. Veterinary pharmaceutical residues from natural water to tap water: sales, occur-rence and fate. I Hazard Mater / L. Charuaud et al. 2019. Vol. 361. P. 169-186. URL: https://doi.org/ 10.1016/j.jhazm at.2018.08.075

Nataliia Karpinska. Legal characteristics of application veterinary and sanitary measures application in animal husbandry

The article is devoted to the characteristics of the legal regulation of care for farm animals and the relationship regarding the use of veterinary drugs from the standpoint of the application of veterinary and sanitary measures through the prism of EU requirements.

A comprehensive analysis of the scientific literature allows us to conclude that in modern legal doctrine the importance of sanitary and phytosanitary measures as an integrating category, a category that stands at the crossroads of agricultural, environmental, social and international policies - is not fully understood and therefore significantly underestimated. Even WTO accession and European integration commitments have not led to a qualitative change in the development of doctrinal principles for reforming legislation, that govers sanitary and phytosanitary requirements in agriculture.

An analysis of the methodological basis of legal support for the use of veterinary and sanitary measures in animal husbandry is conducted, as a result of which three main methodological principles of updating approaches to veterinary and sanitary measures are identified: the impact of active development in many world legal systems of the animal welfare concept; formation of faunal law in the legal system of Ukraine; veterinary safety.

Analyzing the development of domestic legislation on sanitary and phytosanitary measures, it was concluded that the legislative framework in this area is quite extensive, branched, dynamic, so for their qualitative study classification is needed. Accordingly, the relationship between the application of veterinary and sanitary measures in animal husbandry is divided into two groups and characterized: the relationship between the application of veterinary and sanitary measures for keeping farm animals and the relationship of animal quarantine.

The conclusion was substantiated that it is necessary to abandon the automatic implementation of European legislation on the care of farm animals and pay attention to the scientific doctrine in the EU, which sometimes critically evaluates the relevant legislation, pointing to three significant problems arising from progressive EU legislation on animal welfare: slowdown since 2003 in four areas, the normative paradox of animal welfare legislation, in which rules on the commercial use of animals - based on the importance of animals as products - coexist with rules that convey moral respect and protection of animals as intelligent beings and the recognition that most scientific reports on animal welfare prepared by the European Food Safety Authority have not been incorporated into legislation.

Key words: animal husbandry, faunal law, use of veterinary drugs, EU requirements. 